\title{
Um éden nos trópicos: as projeções do paraíso em um móvel colonial
}

\author{
Lourival da Silva Burlamaqui Neto* \\ Universidade Federal de Pernambuco \\ Recife, Brasil \\ Recebido em: 03/04/2019 \\ Aceito em: 31/o7/2019
}

Resumo: Este trabalho propõe a análise iconográfica de um arcaz presente no convento Franciscano de Olinda. Investiga-se a significação que as imagens do móvel, possuíam para o público setecentista. No curso desse exame, essas figuras são associadas com a visão paradisíaca das Américas, tema muito popular nos dois primeiros séculos de colonização. Posteriormente, apresenta-se a definição Pathosformel cunhada por Aby Warburg. Esse conceito pressupõe que a configuração cinética de uma imagem encerra um valor expressivo. Assim, entende-se a profusão de elementos tropicais na peça como uma tentativa de apresentar o Éden americano extasiado, acentuando-se o teor paradisíaco do novo mundo.

Palavras-chave: Arcaz. Motivos edênicos. Pathosformel.

\begin{abstract}
This work proposes the iconographic analize of ancient ark presents on Franciscan convent at Olinda. We investigate the significations of the images in the forniture, for the eighteenth century public. In the course of this exam, these figures are associated with the america's paradisiac vision, a popular theme during the early centuries of colonization. Posteriorly, we presents the pathosformel's definition created by Aby Warburg. This concept presupposes who the cinetic's configuration of an image contains a expressive value. Therefore, we understand the profusion of tropical's elements images on the ark like the representation of american eden on trance, accentuating the heavenly contente of the new world.
\end{abstract}

Keywords: Ark. Edenic motifs. Pathosformel.

Resumen: Este trabajo propone el análisis de un arcaz presente en el convento Franciscano en Olinda. Se investiga la significación que las imágenes, talladas en alto relieve, tenían para los hombres del siglo XVIII. En el curso de este examen, estas figuras se asocian con la visión paradisíaca de las Américas, tema muy popular en los dos primeros siglos de colonización. Posteriormente, se expone la definición Pathosformel creada por Aby Warburg. Este concepto presupone que la configuración cinética de una imagen cierra un valor expresivo. Así, se entiende la profusión de elementos tropicales en el móvil como un intento de presentar el Edén americano en éxtasis, acentuando aún más el contenido paradisíaco del nuevo mundo.

Palabras-clave: Arca. Motivos edénicos. Pathosformel. 


\section{Um texto e um móvel muito estranhos}

Poucas obras do período colonial desconcertam tanto o leitor contemporâneo como Frutas do Brasil (1702) de Frei António do Rosário. Ao contrário do que sugere o título, o livro não é um tratado de botânica produzido por algum religioso ou letrado encantado com a natureza dos novos mundos. $\mathrm{O}$ volume, composto por três parábolas, elenca, na primeira dessas seções, o abacaxi à condição de rei das frutas do Brasil, justificando essa escolha pelo caráter justo que esse apresenta: doce e agradável aos honestos; espinhoso e rígido com os malfeitores.

Essa curiosa analogia inicial logo é substituída por um elogio à contemplação e à reflexão interior. O homem, segundo o frei, é um microcosmo do sistema político e os itens que lhe constituem a alma fazem o papel das instituições presentes nas monarquias: a vontade, por exemplo, corresponde ao conselho de guerra visto que, quando associada ao entendimento, lança guerra contra os desejos da carne.

O clérigo dá sequência à obra, propondo a outros trinta e quatro frutos, a estruturação de três gêneros: o eclesiástico, o nobiliárquico e o popular. O caju, por exemplo, pertenceria ao grupo sacerdotal, pois, à semelhança dos religiosos que, em pares, saem para evangelizar, está em harmonia e concórdia com a castanha, apresentando-se como exempla natural aos disseminadores do cristianismo.

Essa miscelânea de tratado político, livro místico e escrito teológico, além de exemplificar a importância da similitude para as interpretações mediévicas, renascentistas e contra-reformistas, apresenta o impacto que a natureza brasileira exerceu sobre o imaginário europeu. Sérgio Buarque de Holanda, tratando o tema em Visão do Paraíso (2017), demonstrou como um topos da mentalidade medieval, o paraíso terreno, enquadrou as terras da América em uma moldura da imaginação cristã, transformando as plantas e animais tropicais em índices dessa cosmovisão. A obra de António do Rosário, por prescindir das longas descrições e por tratar das frutas brasileiras à medida que essas remetiam a aspectos já 
conhecidos da tradição católica, exemplificava essa postura, contrabalanceando o novo através do uso de lentes antigas ${ }^{1}$. Dessa forma, o texto foi recebido sem reservas por seus censores. Tanto Frei Jerônimo da Ressurreição como Frei Luís da Purificação, ambos lentes do convento de São Francisco em Olinda não pouparam nos elogios ${ }^{2}$.

Alguns anos após a publicação de Frutas do Brasil (1702) chegou ao convento resguardado por esses censores, um móvel que traduzia, para a linguagem da escultura, o fascínio e o estranhamento que a natureza e os nativos da América portuguesa despertavam na imaginação cristã. Tratava-se de um arcaz que, aparentemente, deveria acomodar itens litúrgicos. O móvel, ainda preservado, mede mais de $2,50 \mathrm{~m}$ de altura e é todo composto em jacarandá. A inserção de gavetas e espelhos na estrutura e sua presença no espaço tradicionalmente utilizado como sacristia nos conventos sugere seu emprego no preparo para os ritos clericais ${ }^{3}$.

A fachada do móvel está dividida em cinco eixos. O eixo central é um altar esculpido em talha dourada. Os demais possuem rica decoração em alto-relevo (Figura 1).

\footnotetext{
${ }^{1}$ De certa forma, edenizar a América significava estabelecer com ela uma camaradagem, uma cumplicidade que repousava no mundo imaginário. Encontrava-se aqui algo que, de certa forma, já estava concebido: via-se o que se queria ver, o que se ouvira dizer. (SOUZA, 2005, p. 43)

2 Dizem os censores em suas respectivas licenças: "[...] hu Pytagoras no sentir, por hum Socrates no dividir, por hu Platão no explicar, por hu Aristoteles no inferir [...]" (ROSÁRIO, $1702, \mathrm{~s} / \mathrm{p}) ;$; "[...] as palavras com que prega são animadas com o zelo de sua doutrina, as letras com que escreve são vivificadas com a doutrina do seu zelo; \& verdadeiramente isto basta para que se entenda, que este livro não contem cousa, que a verdade da fé não soe bem, ou a pureza dos costumes soe mal (ROSÁRIO, 1702, s/p)

${ }^{3}$ Não há documentos sobre a encomenda ou confecção do móvel. Estudos como os de Costa (2017) e Carvalho (2013), respectivamente, identificam o móvel com o estilo joanino (décadas iniciais do século XVIII) e datam sua chegada ao convento durante as várias reformas ocorridas na primeira metade do século XVIII.
} 
Figura 1: Arcaz na sacristia do convento de São Francisco

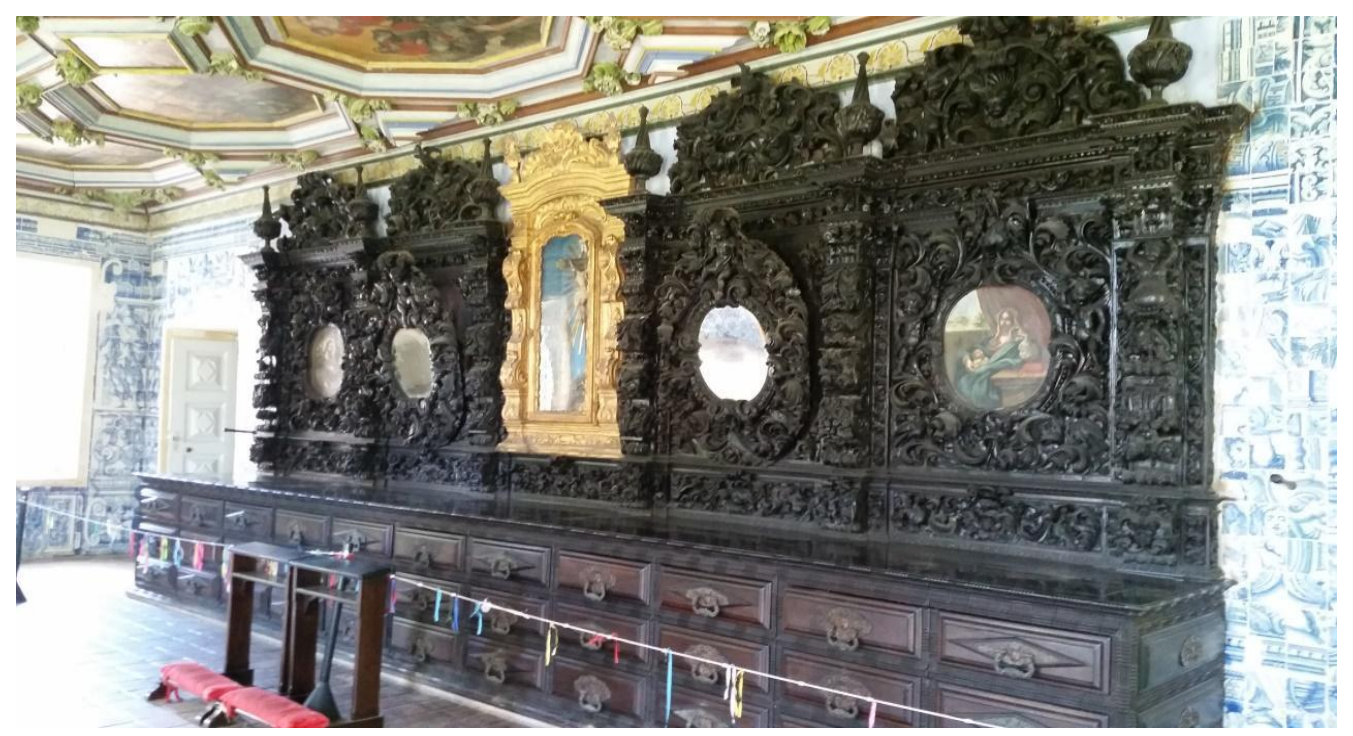

Fonte: Fotografia do autor.

As colunas das extremidades apresentam o mesmo padrão escultórico: um nativo, emergindo de uma folha, faz o papel de atlante ${ }^{4}$ (Figura 2). Essa substituição do titã grego por um indígena não se trata apenas de inserção do pitoresco nativista em um adorno proveniente da arquitetura grega. $\mathrm{O}$ nativo, que sustém um capitel ornado com temas vegetalistas, é a imagem do habitante do novo mundo, força motriz das missões jesuíticas e membro recém-ingresso, através da catequização, na tradição católica.

\footnotetext{
${ }^{4}$ Personagem da mitologia grega que, por insurreição a Zeus, foi condenado a sustentar os céus. Na hélade clássica, sua imagem passou a figurar nas colunas dos templos, constituindo uma estrutura antropomorfa. Pode-se afirmar que esse ornamento possui origemem Homero: "[...] esse que do mar conhece todas as profundezas e segura ele mesmo as colunas potentes, que céu e terra separados mantêm." (HOMERO, 2014, p. 120-121).
} 
Figura 2: Detalhe do atlante na coluna da extremidade.

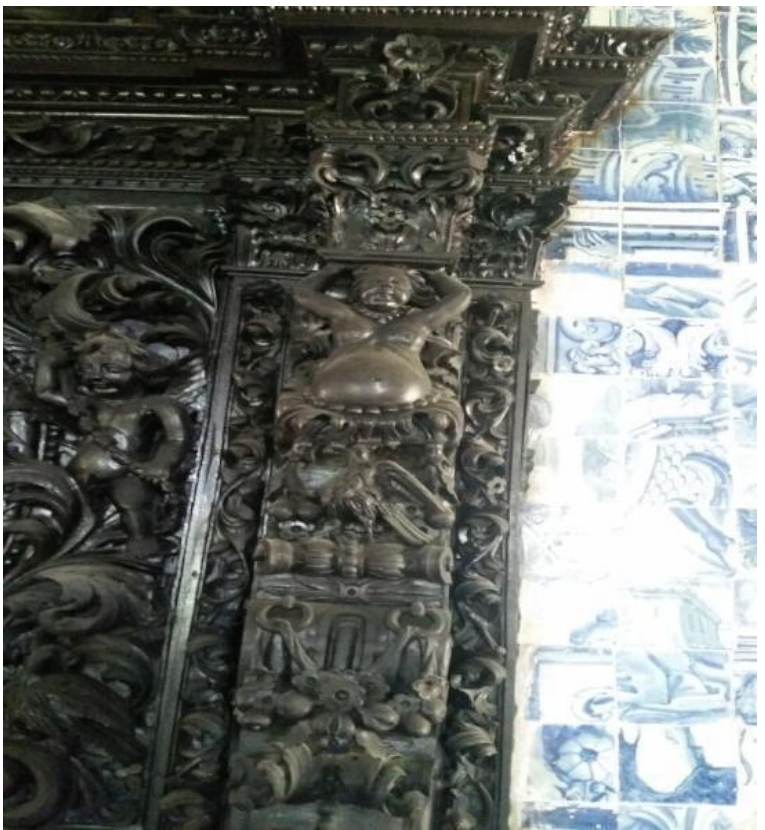

Fonte: Fotografia do autor.

Logo abaixo do indígena, uma ave em posição de canto é rodeada por frutas tropicais e algumas pequenas flores. No quartelão ${ }^{5}$ inferior, frutas (cajus, peras, romãs) e flores pendem de argolas. Seus caules assemelham-se a correntes. Essa metamorfose ${ }^{6}$ de pequenos troncos em grilhões, ou seja, de partes das flores em instrumentos de tortura encontra correspondência na obra de Frei António do Rosário. Ao descrever a flora tropical, o autor interpretava suas cores e formas como índices naturais do calvário: "Nas flores do horto vio a mystica flor do campo as imagens dos seus martyrios e os espelhos da sua payxão; vio nas rosas a purpura de escarneo, e a coroa de espinhos, vio nos cravos os da sua Cruz, nas violetas os vergões dos açoutes [...] (ROSÁRIO, 1702, p. 158, grifo nosso).

O móvel também apresenta duas pinturas rodeadas por enrolamentos fitomórficos. Sobre essas telas, há um pássaro e um pavimento superior no qual o

\footnotetext{
${ }^{5}$ As subdivisões que compõem uma pilastra ornamentada.

${ }^{6}$ Segundo Cassirer, a metamorfose é característica do mito, base da perspectiva religiosa do mundo. Na visão mítica, segundo o filósofo, não ocorre uma divisão rígida entre os entes: "A vida não é dividida em classes e subclasses. Os limites entre as diferentes esferas não são barreiras insuperáveis; são fluentes e flutuantes. [...]. Se existe algum aspecto característico e destacado do mundo mítico, qualquer lei que o governe, é a lei da metamorfose." (CASSIRER, 2016, p. 136). Nas figuras do arcaz, o sentimento religioso anima a transfiguração do caule em grilhão, recorrendo a uma narrativa central do cristianismo: a paixão de cristo.
} 
rosto de um querubim, guarnecido por dois meninos, surge de uma folha longa (Figura 03). Essa mescla de motivos vegetalistas com figuras da ornamentação religiosa sacraliza a natureza, ao mesmo tempo em que extasia e engana o olhar do espectador, visto que as formas de animais, anjos e plantas brotam umas das outras e as bordas que distinguem as silhuetas de cada figura se contorcem em volutas diversas.

Figura 3

Figura 4

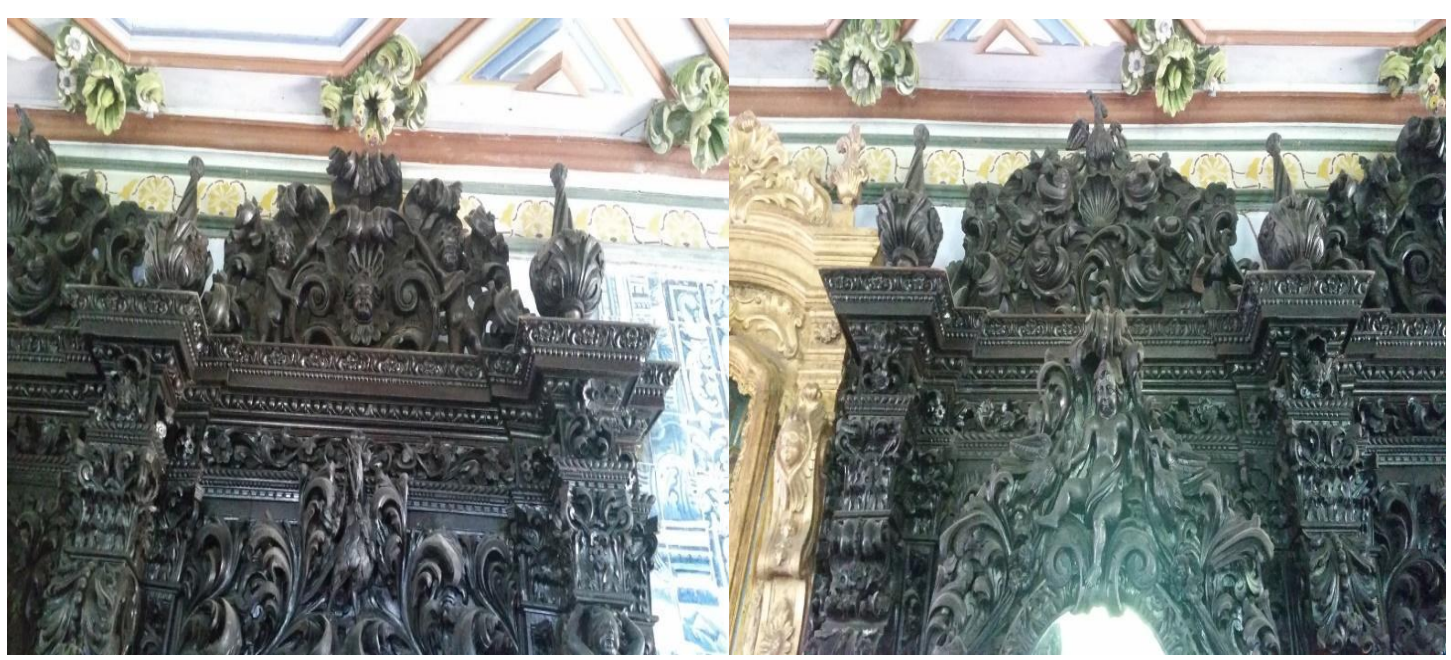

Fonte: Fotografia do autor.

Fonte: Fotografia do autor.

Nas seções intermediárias da fachada há um putti ${ }^{7}$ sorridente e pequenos pássaros sobre um espelho (Figura 04 ). O religioso que mirava ali o próprio reflexo, via-se inserido na projeção de um éden tropical, circundado pela natureza silvestre e pela inocência dos infantes e nativos. Nos pavimentos superiores dessas seções, uma concha e um pelicano rematam a estrutura. Esses dois itens eram os emblemas, respectivamente, de São Tiago e da ressurreição eucarística. Antônio do Rosário (1702, p. 172), em algumas passagens chega a intitular o Cristo com a expressão pelicano divino.

Após essa rápida descrição, é perceptível que o móvel, com exceção do altar em talha dourada, apresenta alguns traços marcantes da estética barroca: a

\footnotetext{
${ }^{7}$ Menino.
} 
profusão, a descontinuidade e o ilusionismo das formas ${ }^{8}$. Assim, rostos e traços humanos surgem da folhagem de madeira, caules parecem correntes e pontos que, à distância são indefinidos, quando vistos de perto, são aves (Figura 5), compondo uma sinuosa metamorfose de contornos. Pouco a pouco, as formas de animais e plantas brotam umas das outras e as bordas que distinguem as silhuetas de cada figura se contorcem em volutas, extasiando e enganando o olhar do espectador.

Figura 5: Detalhe do ornamento da coluna intermediária: pássaros comem frutas.

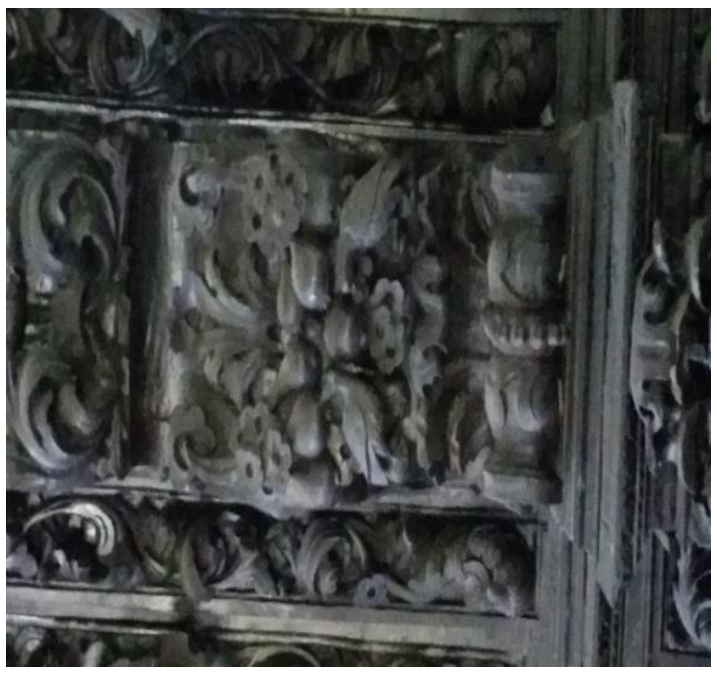

Fonte: Fotografia do autor.

Para além desses vínculos, entretanto, é conveniente observar as singularidades que distinguem os relevos do arcaz das produções canônicas da pintura e da escultura barroca. Essas distinções são de natureza iconográfica, ou seja, os temas, as figuras presentes no móvel estão associadas à América portuguesa. Tem-se a impressão de que, embora destinado a um ambiente religioso, as imagens do espaldar não dizem respeito ao empíreo, mas à realidade terrena. Por que ressaltar plantas, animais e nativos do continente americano

\footnotetext{
${ }^{8}$ Há, portanto, em toda a arte barroca, declarada propensão para uma forma que se abre em indeterminação de limites e imprecisão de contornos, uma forma que apela para os recursos da impressão sensorial, que não quer apenas conter a informação estética, mas sobretudo comunicá-la sob um grau de tensão que transporte o receptor, o espectador, da simples esfera de plenitude intelectual e contemplativa para uma estesia mais franca e envolvente - mais do que isso, para um êxtase dos sentidos sugestionadamente acesos e livres. (ÁVILA, 1970, p. 8)
} 
nessa peça religiosa? À semelhança de Frutas do Brasil (1702), esse móvel seria a materialização de um amoldamento da natureza brasileira a algum padrão mental da cosmovisão cristã do mundo?

\section{Um paraíso nas Américas: gênese e decadência de uma imagem}

Uma resposta possível para esses questionamentos passa pela semelhança entre os relevos do arcaz e uma imagem que no século XVIII já estava se esvaindo: a imagem do Paraíso terreal. Esse antiquíssimo mito do imaginário europeu propunha que, em algum lugar da terra, cercado por uma natureza virgem e exuberante, estaria o jardim do Éden habitado pelo homem sem pecado e, consequentemente, sem pejo. Essa narrativa, como demonstrou Sérgio Buarque de Holanda (2017, p. 53-78), se tornou bastante popular durante os descobrimentos e a tradição católica pôs, lado a lado com a memória do paraíso perdido, a expectativa de um paraíso reencontrado. Assim, navegantes, clérigos e populares, mantendo contato com as novas regiões do globo, ou com os relatos sobre elas, averiguavam com assombro e curiosidade as espécies de plantas e animais presentes nesse Éden de além-mar e associavam a ingenuidade dos nativos com a pureza do adão bíblico. Laura de Mello e Souza (2005, p.35), a esse respeito, comenta: "Era pois generalizada, sobretudo entre os eclesiásticos, a ideia de que o descobrimento do Brasil fora ação divina, de que entre os povos, Deus escolhera os portugueses [...]. Ação divina, o descobrimento do Brasil desvendou aos portugueses a natureza paradisíaca [...].”

Frequente entre os séculos XVI e XVIII, essa associação das terras da América com a imagem do paraíso possuía íntima relação com a natureza messiânica da religião cristã. Para os cristãos, após os tempos de plenitude descritos no Gênesis e após a primeira vinda do Messias presente nos evangelhos, decorreram a decadência e o infortúnio. Esses males apenas seriam redimidos no futuro, quando o retorno do cristo iria depurar as relações entre os homens, 
instaurando um novo tempo. Adequando-se à noção de espaço, o messianismo propunha a restituição de um paraíso perdido e, no contato entre europeus e nativos, semelhanças entre a realidade empírica e essa projeção paradisíaca do imaginário cristão permitiram o amoldamento da América às ideias de tempo redentor e espaço prometido.

É possível observar que essa representação edênica da América, como toda imagem messiânica, projetava um futuro mais próximo do passado que do presente, reatando os laços entre o tempo por vir e um passado mítico ${ }^{9}$. Justamente por isso, as passagens bíblicas são frequentemente elencadas à condição de referência comparativa quando se trata das novas terras. Frei Simão de Vasconcellos, descrevendo as aves do Brasil, apontava semelhanças entre essas e as que habitavam o paraíso:

A mesma bondade proporcional se acha nas aves desses ares. Todo o universo não vio espécies, nem mais em numero, nem mais fermosas: parecem as mesmas dos primitivos ares, antes criadas no mesmo Paraíso da terra: tal he a bondade, o numero, \& a variedade de sua fermosura [...] (VASCONCELLOS, 1668, p. 281-282, grifo nosso)

Padre Antônio Vieira, discorrendo sobre a colônia, amolda a matéria histórica à narrativa cristã e interpreta dados objetivos a partir da cosmologia católica:

\begin{abstract}
Uma das coisas mais notáveis que Deus revelou e prometeu antigamente, foi, que ainda havia de criar um novo Céu, e uma nova terra. Assim, o disse por boca do Profeta Isaías: Ecce ego creo Coelos novos, et terram novam. [...] logo, que terra nova, e que Céus novos são estes, que Deus tanto tempo antes prometeu que havia de criar? Outros o entendem de outra maneira, não sei se muito conforme à letra. Eu, seguindo o que ela simplesmente soa e significa, digo que esta nova terra e estes novos Céus, são a terra e os Céus do Mundo Novo descoberto pelos Portugueses. (VIEIRA, 2014, p. 596-598, grifo nosso)
\end{abstract}

\footnotetext{
${ }^{9}$ Mircea Eliade (2017, p. 48) observa que essa restituição futura de uma condição primitiva, caracterizadora do messianismo, possui raízes em uma concepção cíclica do tempo: "Não obstante, há um fato que nos parece essencial: os egípcios, os mesopotâmios, os hebreus e outros povos do antigo Oriente próximo sentiam a necessidade de renovar periodicamente o mundo. Essa renovação consistia num enredo cultural, cujo rito principal simbolizava a repetição da cosmogonia."
} 
O religioso, para justificar a condição de paraíso reencontrado, chega a propor uma analogia entre os grandes mares dos quais, segundo o Gênesis, surgiu o Éden e o oceano atlântico navegado pelos Portugueses:

\begin{abstract}
Quando Deus criou o mundo, diz o sagrado Texto, que a terra não se via porque estava escondida debaixo do elemento da água, e toda escura e coberta de trevas [...]. Então dividiu Deus as águas, e apareceu a terra: criou a luz e cessaram as trevas [...]. Este foi o modo da primeira criação do mundo. E quem não vê que o mesmo observou Deus na segunda por meio dos Portugueses? (VIEIRA, 2014, p. 598, grifo nosso)
\end{abstract}

Além dessa associação direta entre um passado mítico, geralmente caracterizado como tempo de bonança, e o futuro, outros traços marcantes do messianismo são: I) o menosprezo pelo presente, tido como um tempo de espera e privações; II) a sua variabilidade no imaginário de grupos sociais distintos.

Agamben (2016), comentando o primeiro aspecto, pondera que, a imagem messiânica consola do presente,à medida que se apresenta como possibilidade,impulsionando os crentes a buscá-la. Desse modo, o paraíso terreal surgia, aos homens dos séculos XVI, XVII e XVIII, como uma compensação aos padecimentos do tempo em que viviam.

Tratando a segunda característica, o filósofo afirma que, embora provenham da tradição cristã e de sua crença no retorno do cristo, o messianismo e suas consequentes projeções redentoras se enraizaram na cultura ocidental e passaram a possuir íntima relação com as memórias dos grupos nos quais os homens se organizam: nação, religião, classe social, dentre outros. Ou seja, o homem quando vivencia a experiência dessas coletividades, recebe, sob a forma de uma trama, memórias coletivas. Esse enredo segue a dinâmica memória/esquecimento e pressupõe continuidade. A sequência dessa trama será escrita pelos novos partícipes de tais grupos, os quais farão as projeções do tempo que virá. Esse tempo ou será tão grandioso quanto o passado ou irá superá-lo, redimindo o presente. Assim, para Agamben (2016, p. 55) essas projeções redentoras pressupõem um "[...] sujeito, que presta de uma vez por todas as contas com as suas pretensões identitárias [...]”. Esse vínculo entre imagem messiânica e a narrativa de um grupo explica porque a visão edênica do novo 
mundo não foi unanimidade entre os que aportaram na América. Tratando-se, nos domínios portugueses, de uma imagem mais difundida entre ordens religiosas.

Após essas rápidas considerações sobre a natureza messiânica do paraíso terreal, convém observar que, no início século XVIII, período de construção do arcaz, embora as missões jesuíticas prosperassem e outras ordens religiosas ampliassem suas ações, a constituição etnográfica, política e social da colônia portuguesa já era bem distinta da encontrada pelos religiosos ao chegarem na terra brasilis dois séculos antes. A ganância dos colonos, o consequente genocídio de nativos e as desavenças entre políticos e religiosos portugueses, no que dizia respeito à colônia, passava a ideia de que o estado paradisíaco estava, gradativamente, se esvaindo ${ }^{10}$. Dessa forma, de projeção futura, reconstituinte de um passado mítico, a imagem do paraíso terreal transformou-se em saudosismo por um passado recente e passou a condensar dois tempos: a temporalidade mítica associada à Bíblia e a ocasião do encontro com o novo Éden no século XVI.

George Didi-Huberman (200o, p. 16-18), analisando os diversos passados que constituem qualquer imagem, afirma que "Nous voici bien devant [...] un objet de temps complexe, de temps impur: un extraordinaire montage de temps hétérogènes [...]. L’image est hautement surdéterminée: elle joue, pourrait-on dire, sur plusiers tableaux à la fois"11. Desse modo, compostos no século XVIII, os relevos do arcaz já não constituíam apenas a imagem redentora do éden terreal,

\footnotetext{
${ }^{10}$ Vieira, em alguns de seus sermões, observava como a atividade dos jesuítas tornou-se malvista pelos colonos. Esses donatários, interessados em utilizar os nativos como mão de obra escrava, se insurgiam contra os agentes responsáveis pela catequização, expulsando-os de suas capitanias. Assim, o pregador questionava "Quem havia de crer, que em uma colônia chamada de Portugueses se visse a igreja sem obediência, as Censuras sem temor, 0 Sacerdócio sem respeito, e as pessoas e lugares sagrados sem imunidade?" (VIEIRA, 2014, p. 600), rematando seu raciocínio com agudeza: "[...] Foge Cristo e fogem os Pregadores de Cristo, dos Fiéis para os Infiéis, e dos cristãos para os gentios, porque os Cristãos os desterram, e os Gentios os amparam [...]" (VIEIRA, 2014, p. 604). Sérgio Buarque (2017, p. 230), por sua vez, chama a atenção para o inevitável choque entre a imagem edênica da América e o cotidiano do novo mundo. Esse confronto, segundo o historiador, paulatinamente, ocasionaria o esvaziamento da primeira: "Contudo, esse mundo paradisíaco, fosse ele cristão ou pagão, permanecia invariavelmente no passado, ou no futuro, ou no sonho, alheio e adverso à vida atual. Esquecidos de que o próprio de todos os ideais é serem inatingíveis [...]". 11 "[...] estamos [...] diante de um objeto de tempo complexo, de tempo impuro: uma extraordinária montagem de tempos heterogêneos [...]. A imagem está fortemente sobredeterminada: ela joga, se poderia dizer, com vários quadros ao mesmo tempo [...]" (Tradução nossa)
} 
tornando-se, ao mesmo tempo, a projeção de um paraíso que, no instante de sua descoberta, fora também perdido. Ou seja, durante a construção do arcaz, essa imagem da América como lugar paradisíaco tratava-se de uma representação do continente não como ele era naquele instante, mas como o homem do século XVI achava que ele fosse (projeção) e como os do século XVIII gostavam de acreditar que ele havia sido (saudosismo). Imagem de um futuro aguardado que, persistindo no imaginário, se transformou no quadro idealizante de um passado. Anacronismo, no sentido que Didi-Huberman (2006, p. 18, tradução nossa) dá a esse termo: "O anacronismo seria assim, em uma primeira aproximação, o modo temporal de expressar a exuberância, a complexidade, a sobredeterminação das imagens."

\section{O triunfo do éden tropical}

Após essa identificação do alto-relevo presente no arcaz com a imagem edênica, convém averiguar por que a natureza na peça é apresentada em êxtase. A exuberância de formas seria fruto somente da filiação à estética barroca? As imagens frenéticas que se intercalam em contornos fluidos podem ser compreendidas, à parte do tema geral? Uma tentativa de resposta para esses questionamentos pode ser colhida nas reflexões e nos conceitos desenvolvidos por Aby Warburg, historiador da arte alemão. Na sua incompleta e enigmática Introdução à Mnemosine (2015), Warburg propôs lançar luz sobre os padrões expressivos humanos presentes no movimento. Segundo o autor alemão, o homem possui um vocabulário de valores energéticos que são efetivados nos gestos. Essas potências enunciativas, ao serem materializadas e consumadas na ação, originariam ou o ato efusivo, exprimindo algum arrebatamento, ou a atitude comedida. Para conhecer esses valores expressivos pré-formados (WARBURG, 2015, p. 365), o historiador judeu inventariou as várias consumações artísticas de cada padrão energético, pondo-as lado a lado em pranchas (Figura 
6). No alto é possível observar o arco de Constantino, na parte de baixo há um afresco retratando a apoteose de Napoleão, no centro, um camafeu apresenta a corte de Augusto, à esquerda, mais um afresco delineia a ascensão de Vênus, dentre outros. A comparação entre essas diversas efetivações permitiria o conhecimento do pathosformel ${ }^{2}$.

Figura 6: Prancha $n^{\circ}$ o7, contendo diversas consumações do pathosformel triunfo.

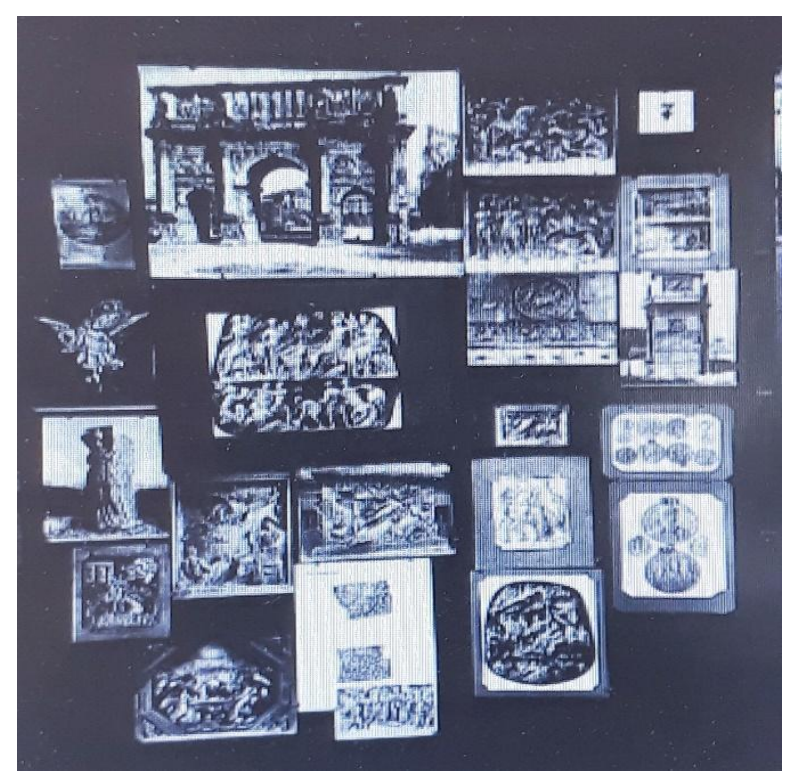

Fonte: Warburg, 2010

As várias concretizações de um pathosformel demonstrariam sua recorrência, sua sobrevivência (Nachlaben) no curso do tempo. Warburg, porém, observa que na passagem de uma cultura para outra, um pathosformel poderia sofrer uma ressignificação. O autor exemplifica esse processo mencionando a presença do zodíaco em antigos sarcófagos pagãos. Na antiguidade, essas peças ilustravam a mitologia e sua influência no cotidiano de gregos e romanos. Posteriormente, no Renascimento, essa sistematização do cosmos seria

\footnotetext{
${ }^{12}$ Pathos (Paixão, afecção) + Formel (Fórmula). Agamben, apontando as peculiaridades desse conceito, observa que o cotejo entre as diversas materializações de um pathos não remeteria 0 observador a um conteúdo abstrato que prescindisse da imagem. O pathosformel apenasseria compreendido e conhecido na constelação de imagens em que se materializa, emergindo e permanecendo preso a elas, ou seja, "[...] não é possível distinguir entre forma e conteúdo porque designa um indissolúvel entrelaçamento de uma carga emotiva e de uma fórmula iconográfica" (Agamben, 2015, p. 112-113).
} 
incrustada em ambientes cristãos, funcionando como alegoria da caminhada dos romeiros:

[...] as sagas nos relevos pagãos expunham, em símbolos míticos, a luta desesperadora pela ascensão da alma humana ao céu. Aquela série com mais de doze sarcófagos encravada nas laterais da escadaria de Santa Maria Aracoeli mostra quão enfaticamente tais elementos hostis à Igreja podiam de inculcar; autorizadas a acompanhar o peregrino devoto em sua subida à Igreja, estão ali como imagens oníricas vindas da região proibida do ímpio demonismo pagão. (WARBURG, 2015, p. 373-374)

Essa sobrevivência (Nachlaben) de um pathos e sua consequente ressignificação ou modelação operada por culturas distintas passaria pela memória. O autor judeu acreditava que a interação social entre o indivíduo e a massa, ou seja, os grupos dos quais faz parte, poderia cravar, na memória individual, determinados padrões expressivos, sob a forma de pulsões. Posteriormente, essa carga expressiva de natureza mnêmica seria retransmitida novas imagens e, gradativamente, atualizada no contato com novos constructos culturais ${ }^{13}$.

Mas como esses conceitos de Warburg podem auxiliar na compreensão dos relevos presentes no arcaz? As imagens esculpidas no espaldar do móvel apresentam uma natureza em frênesi: flores e folhas se entrelaçam, pássaros devoram frutas, conchas rebentam, rostos surgem de formas fitomórficas, enfim, os trópicos parecem estar em êxtase. Essa apoteose, expressa na quantidade excessiva de formas, apresenta-se também no movimento exuberante: ramos e folhas de acanto se cruzam em intrincadas volutas, pequenos animais estão em posição de regozijo, nativos esforçam-se para sustentar parte do conjunto e os pelicanos possuem porte altaneiro. O grande número e o movimento frenético dessas figuras permitem a leitura do relevo como uma materialização artística do

13 O texto O Déjeuner sur l'herbe de Manet (2015), passagem que integraria o Atlas Mnemosine, ilustra bem parte desse processo. Nesse escrito, Warburg, investigando a conhecida tela do pintor francês e outras obras materializadoras do mesmo pathosformel, observa como pequenas alterações no vocabulário gestual das personagens indicariam novas relações entre os homens e a natureza e novas formas de compreensão da segunda. 
pathosformel triunfo ${ }^{14}$. Para Warburg (2015), alguns traços marcantes da consumação desse pathos seriam o movimento arrebatador e o fluxo alucinado de uma turba junto a um governante. Dessa forma, a natureza extasiada do espaldar estaria em frenesi por conta dos itens presentes no eixo mediano: o crucifixo e dois relicários. Ou seja, a multidão de guerreiros e demais personagens apresentados nos relevos e esculturas do arco de Constantino, outra materialização desse pathos, deram lugar aos bichos e plantas brasileiros enlevados pela presença de um líder que ultrapassa o mundo físico. A dimensão triunfal, apoteótica das figuras no arcaz, dessa forma, seria a materialização dos trópicos em êxtase, a projeção do novo éden, arrebatado pela presença do ícone cristão.

Um painel figurativo composto em azulejaria portuguesa e presente no convento de Santo Antônio, região central do Recife, é outra concretização cristã desse pathosformel (Figura 7). Na cercadura da obra, produzida no século XVIII, há uma legenda com uma descrição parcial da imagem: "Vendo os catholicos perceguidos pelo grande rei dos inimigos da Fé se armarão com o Rozario e destruirão." Sílvia Guimarães Borges (2009) interpreta o painel como a representação pictórica do conflito entre os reinos católicos e os turcos otomanos na batalha de Lepanto.

Figura 7: Painel composto em azulejos portugueses na capela do Rosário do convento de Santo Antônio.

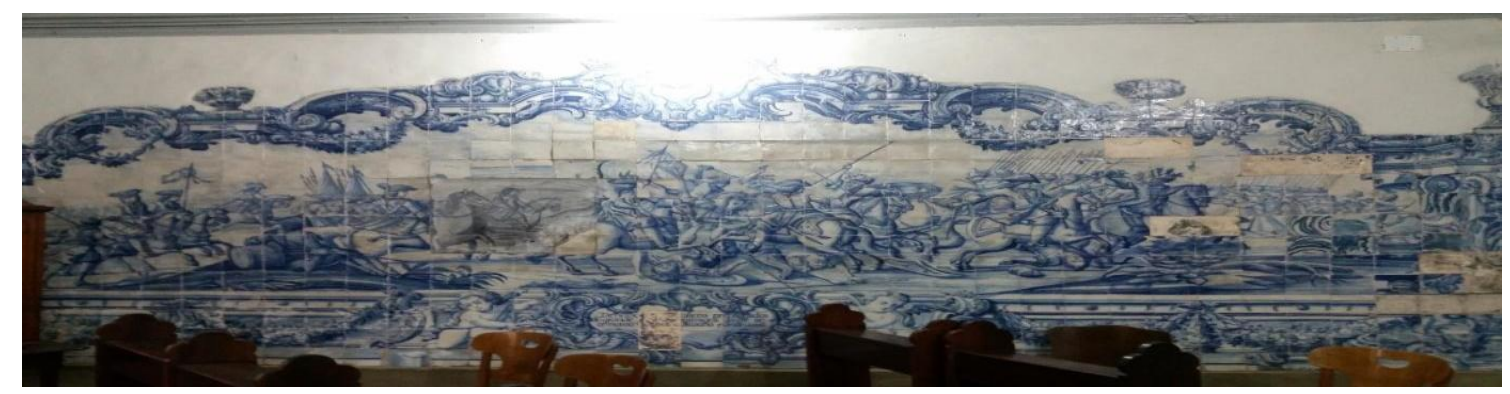

Fonte: Fotografia do autor.

${ }^{14}$ Esse pathos está exposto no painel $n^{\circ} 7$ do Atlas Mnemosine (Ver figura 06) 
Na imagem, o movimento frenético dos cavalos que pisoteiam orientais, os gestos imponentes dos cristãos com espadas em punho e a massa indiscernível dos turcos em retirada, à medida que os católicos avançam, conferem uma grandeza triunfal ao episódio, exemplificando “[...] aquele páthos imperial que, por sua eloquência ruidosa e cativante, conferiu validade universal à linguagem gestual de seus descendentes tardios [...]" (WARBURG, 2015, p. 370, grifo nosso).

\section{Referências}

AGAMBEN, Giorgio. Aby Warburg e a ciência sem nome. IN: A potência do pensamento: ensaios e conferências. Tradução: António Guerreiro. Belo Horizonte: Autêntica, 2015.

- O tempo que resta: um comentário à Carta aos Romanos. Tradução:DaviPessoa.Belo Horizonte: Autêntica, 2016.

ÁVILA, Affonso. O elemento lúdico nas formas de expressão do Barroco. IN: ÁVILA et al. Barroco 02. Belo Horizonte: Imprensa da Universidade Federal de Minas Gerais, 1970.

BENJAMIN, Walter. O anjo da história. 2. ed. Belo Horizonte: Autêntica Editora, 2016.

CARVALHO, Anna Maria F. Monteiro de. O complexo construtivo franciscano de Olinda no Brasil Colonial: Aspectos sócio urbanos, arquitetônicos e artísticos. IN: Os Franciscanos no mundo português III: o legado franciscano. Porto: CEPESE, 2013.

CASSIRER, Ernst. Ensaio sobre o Homem: introdução a uma filosofia da cultura humana. Tradução: Tomás Rosa Bueno. 2. ed. São Paulo: Editora WMF Martins Fontes, 2016.

COSTA, Rafael Ferreira. A sacristia do convento de São Francisco de Olinda. 2017. Dissertação (Mestrado em História da arte Portuguesa) - Faculdade de Letras da Universidade do Porto, Universidade do Porto, Porto, 2017. 
DIDI-HUBERMAN, George. Devants le temps: histoire de l'art et anachronisme des images. Paris: Éditions de minuit, 2010.

ELIADE, Mircea. Mito e realidade. Tradução: Pola Civelli. 6. ed. São Paulo: Perspectiva, 2016.

HOLANDA, Sérgio Buarque de. Visão do Paraíso: os motivos edênicos no descobrimento e colonização do Brasil. São Paulo: Companhia das Letras, 2010.

HOMERO. Ilíada. Tradução: Frederico Lourenço. São Paulo: Penguin Classics Companhia das letras, 2013.

ROSÁRIO, António do. Frutas do Brasil numa nova e ascetica Monarchia. Lisboa: Officina de Antonio Pedrozo Galrão, 1702.

SOUZA, Laura de Mello e. O Diabo e a Terra de Santa Cruz: feitiçaria e religiosidade popular no Brasil colonial. São Paulo: Companhia das letras, 2005.

VASCONCELLOS, Simão de. Noticias curiosas e necessárias das cousas do Brasil. Lisboa: Officina de Joam da Costa, 1668.

VIEIRA, Antonio. Sermões. Organização e introdução: Alcir Pécora. São Paulo: Hedra, 2014.

WARBURG, Aby. Atlas Mnemosyne. Madrid: Ediciones Akal, 2010. Histórias de fantasmas para gente grande: escritos, esboços e conferências. Tradução:Lenin Bicudo Bárbara.São Paulo: Companhia das Letras, 2015.

*Doutorando em Teoria da Literatura pela Universidade Federal de Pernambuco (UFPE). 